\title{
Biomimetic mineral-organic composite scaffolds with controlled internal architecture
}

\author{
I. MANJUBALA ${ }^{1, *}$, ALEXANDER WOESZ $^{1}$, CHRISTINE PILZ $^{1}{ }^{1}$, MONIKA RUMPLER $^{1}$, \\ NADJA FRATZL-ZELMAN ${ }^{2}$, PAUL ROSCHGER ${ }^{2}$, JUERGEN STAMPFL ${ }^{3}$, \\ PETER FRATZL ${ }^{1, *}$ \\ ${ }^{1}$ Max Planck Institute for Colloids and Interfaces, Department of Biomaterials, 14424 \\ Potsdam, Germany \\ E-mail:i.manjubala@mpikg.mpg.de; fratzl@mpikg.mpg.de \\ ${ }^{2}$ Ludwig Boltzmann Institute of Osteology at the Hanusch Hospital of WGKK and AUVA \\ Trauma Centre Meidling, 4th Medical Department, Hanusch Hospital, 1140 Vienna, Austria \\ ${ }^{3}$ Institute of Materials Science and Technology, Vienna University of Technology, 1040 \\ Vienna, Austria
}

Bone and cartilage generation by three-dimensional scaffolds is one of the promising techniques in tissue engineering. One approach is to generate histologically and functionally normal tissue by delivering healthy cells in biocompatible scaffolds. These scaffolds provide the necessary support for cells to proliferate and maintain their differentiated function, and their architecture defines the ultimate shape. Rapid prototyping (RP) is a technology by which a complex 3-dimensional (3D) structure can be produced indirectly from computer aided design (CAD). The present study aims at developing a 3D organic-inorganic composite scaffold with defined internal architecture by a RP method utilizing a 3D printer to produce wax molds. The composite scaffolds consisting of chitosan and hydroxyapatite were prepared using soluble wax molds. The behaviour and response of MC3T3-E1 pre-osteoblast cells on the scaffolds was studied. During a culture period of two and three weeks, cell proliferation and in-growth were observed by phase contrast light microscopy, histological staining and electron microscopy. The Giemsa and Gömöri staining of the cells cultured on scaffolds showed that the cells proliferated not only on the surface, but also filled the micro pores of the scaffolds and produced extracellular matrix within the pores. The electron micrographs showed that the cells covering the surface of the struts were flattened and grew from the periphery into the middle region of the pores. (C) 2005 Springer Science + Business Media, Inc.

\section{Introduction}

Bone is a natural cellular solid with hierarchical structure. At the ultrastructural level of hierarchy, bone is a polymer-inorganic nanocomposite and at the microstructural level it consists of mineralized collagen fibrils arranged in lamellae and of interconnected pores. The properties of the whole bone are dependent on all levels of hierarchy [1-3]. An ideal bone implant should exhibit the interconnected micro and macro pores of natural bone and should have a nanocomposite structure and composition similar to bone. One approach in bone tissue engineering involves production of scaffolds and seeding of bone cells on the scaffolds and utilising them for implantation [4-6]. The shape, architecture and surface of the scaffold are crucial as they enable the cells to proliferate, migrate and differentiate and also to produce extracellular matrix to generate new tissues. Moreover, interconnected porosity is necessary for vascularisation, which is required to support the cells proliferation deep into the interior of the scaffold $[7,8]$.

Porous materials have been used as bone implants for many years. The internal architectural attributes, including pore size, shape and connection pattern, play an important role in the in-vivo and mechanical performance of the implants. They control the degree of bone regeneration [9-14], path of bone regeneration [15] and determine the mechanical properties of the implants [16-19]. However, traditional processing methods, mainly particle leaching technique [20], solution casting [21] and melt molding [22] result in random architecture and provide minimal control over the internal architecture of the implants thus preventing the optimization of the engineered bone tissue. Usually conventional fabrication techniques produce scaffolds that are foam structures. A further disadvantage of such a random

*Author to whom all correspondence should be addressed. 
architecture is that the pore size and pore channels are not properly designed. Therefore, rapid prototyping (RP) is a technology which allows to produce a complex three dimensional (3D) structures of scaffolds with controlled architecture [23-25]. This offers advantages for tissue engineering as it permits control of the internal architecture of the scaffolds, such as pore size, porosity and pore distribution, throughout the scaffold.

Furthermore, the choice of the proper materials is crucial. Biodegradable polymers capable of forming cellular foams and calcium phosphate ceramics (hydroxyapatite (HA) and tricalcium phosphate or a mixture of both, biphasic calcium phosphate (BCP)) have been used as scaffold materials [26-28]. The latter materials resemble natural bone inorganic material and are osteoconductive, but their brittleness limits their applicability in load bearing applications. As bone itself is a reinforced polymer matrix - ceramic (collagen-hydroxyapatite) composite, a polymer based HA composite is a promising material as bone implant.

Several natural biodegradable polymers are known, among which chitosan is well suited for tissue engineering. Apart from being bioresorbable, it is biocompatible, non-toxic, non-antigenic and biofunctional [29]. The primary chemical unit of chitosan is 2-amino-2deoxy-D-glucose linked by $\beta, 1-4$ glucosidic linkage, and analog to GAG (glucoseaminoglycan) [30]. The advantage of chitosan over synthetic polymers is that chitosan has a hydrophilic surface promoting cell adhesion, proliferation and differentiation and evokes a minimal foreign body reaction on implantation [31]. A promising feature of chitosan is its excellent ability to be processed in porous structures used in cell transplantation and tissue engineering [32]. In vitro and in vivo studies have shown that chitosan sponges are osteoconductive and can enhance bone formation. The cells attach to the scaffolds, differentiate, multiply and grow producing extracellular matrix and finally form a bone like material [33].

Chitosan-hydroxyapatite composites have already been used as a bone substitute material $[34,35]$. A limitation in these composite scaffolds is that they have random internal architecture. Our goal is to produce composite scaffolds with controlled internal architecture. In a previous paper, we have already reported the use of digital light processing (DLP) to produce epoxy resin molds for the production of HA scaffolds by ceramic gel casting [36]. The present study is to utilise a rapid prototyping technique to produce dissolvable molds. Casting of these molds with chitosan-hydroxyapatite composite material yields scaffolds with designed macro porosity and reproducible micro porous inner architecture. Preliminary in vitro tests to validate these new scaffolds for use as bone replacement material were carried out with the pre-osteoblastic MC3T3-E1 mouse derived cell line.

\section{Materials and methods}

\subsection{Materials}

Chitosan (MW 150,000, viscosity $200 \mathrm{mPas}$, 85\% deacetylation) was obtained from Fluka Biochemicals
Ltd. Chitosan was purified as follows: the raw-chitosan was dissolved in $2 \%$ acetic acid aqueous solution until a homogeneous $1 \%$ chitosan solution was obtained. This solution was neutralised to $\mathrm{pH} 9.0$ with a $10 \%$ $\mathrm{NaOH}$ solution to precipitate chitosan and the precipitate was then washed well with deionised water and dried. Commercial hydroxyapatite powder (average particle diameter of $5 \mu \mathrm{m}$ ) used for composite preparation was purchased from Plasma Biotal, UK. Acetic acid and sodium hydroxide (analytical grade) was purchased from Merck $\mathrm{GmbH}$ and ethanol (analytical grade) from Fischer Organics, Germany. The cell culture media ( $\alpha$-MEM), glucose, gentamicin and ascorbic acid are purchased from Sigma Aldrich, Germany.

\subsection{Scaffold formation by an indirect rapid prototyping fabrication process}

An indirect fabrication process was used, in which the scaffolds were obtained from dissolvable molds, produced by RP. Molds with the required negative shape, were designed using the commercial CAD software Pro-Engineer (PTC Needham, Massachusetts, USA). The STL file from the virtual CAD design were transferred to a 3D printer (Solidscape, Model Maker II), which prints two different wax materials, build-wax (protobuild) and support-wax (protosupport). The liquid wax is fed to individual jetting heads, which squirt tiny droplets of the materials as they are moved in $\mathrm{X}-\mathrm{Y}$ fashion in the required pattern to form a layer of the object. The wax materials harden by rapid drop in temperature as they are deposited. After a layer is completed, a horizontal rotary cutter is used to flatten the top surface and control the thickness, as shown by a schematic representation in Fig. 1. The platform is lowered and the process is repeated to build the next layer, which adheres to the previous layer, until the model is completed. After the mold printing is completed, the support wax material was dissolved in Dewasol solution (Solidscape Inc.) at $55^{\circ} \mathrm{C}$ with constant stirring. The molds were subsequently air-blown to remove the Dewasol in the interior of the design and stored in vacuum for further use.

Chitosan solution with concentration of $1 \mathrm{wt} \%$ was prepared by dissolving chitosan in $1 \%$ acetic acid solution. The mixture was stirred at $50{ }^{\circ} \mathrm{C}$ for $5 \mathrm{~h}$ to obtain a homogeneous viscous polymer solution and filtered to remove air bubbles trapped in the viscous solution. A slurry mixture consisting of chitosan solution and hydroxyapatite powder was prepared at a composition of 60:40 weight ratio. The slurry was cast into molds in vacuum and rapidly transferred into a freezer (Ultralow temperature freezer, Profiline Aurus PLTA) preset at a temperature of $-80^{\circ} \mathrm{C}$ to solidify the slurry. The solidified mixture was retained at $-80^{\circ} \mathrm{C}$ for $2 \mathrm{~h}$. The frozen molds filled with composite were then treated with $10 \%$ alcoholic sodium hydroxide solution which acts as a solvent for mold wax material and ice crystals. Afterwards, scaffolds were then critical point dried with liquid carbon dioxide using a critical point dryer (BAL-TEC, AG/CPD 030) and stored in vacuum. 


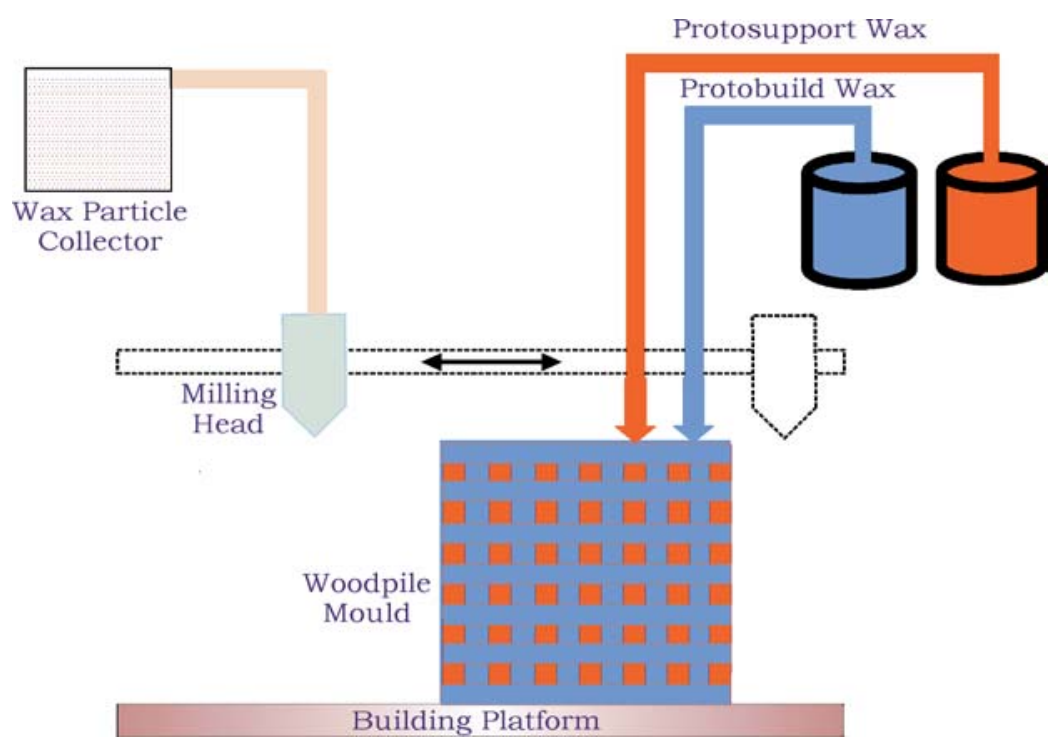

Figure 1 Schematic representation of the working principle of Solidscape (Model Maker II) 3D printer showing the building process of a mold with two different wax materials.

The phase composition of the composite was checked with a powder X-ray diffractometer (D8 X-ray diffractometer, Bruker AXS Ltd., UK). The surface morphology of the scaffolds was observed with an environmental scanning electron microscope (Quanta 600 FEG, FE-ESEM, FEI Europe) to observe the effect of imprints of the molds on the scaffolds. The local mechanical property of the composite strut in the scaffold was assessed by nanoindentation (Triboscan nanohardness tester, Hysitron, USA) in dry condition.

\subsection{Cell culture experiments}

The pre-osteoblastic mouse calvarie MC3T3-E1 cell line (generous gift from Dr. F. Varga, Ludwig Boltzmann Institute of Osteology, Vienna, Austria) was used for in vitro studies. The volume of the overall pores of the scaffold was predetermined. $1 \times 10^{6}$ cells were resuspended in culture medium of same volume and seeded on the scaffold by dropping the cell suspension directly onto the scaffold pores. The medium was $\alpha$-modified Eagle's medium ( $\alpha$-MEM) with $4.5 \mathrm{~g} / \mathrm{l}$ glucose, $10 \%$ fetal calf serum (FCS), $10 \mu \mathrm{g} / \mathrm{ml}$ gentamicin and $50 \mu \mathrm{g} / \mathrm{ml}$ ascorbic acid [36, 37]. The scaffolds with cells were incubated at $37^{\circ} \mathrm{C}$ for $2 \mathrm{~h}$ to allow the cells to attach to the material and then $2 \mathrm{ml}$ of medium were added into every well. The cells were allowed to grow up to 4 weeks. The medium was changed twice a week with freshly prepared medium. The cell adhesion, proliferation and distribution over the scaffold was analysed using a phase-contrast microscope (Nikon Eclipse TS100, Germany) after a period of 1 and 2 weeks of cell culture.

\subsection{Alkaline phosphatase activity measurements}

Alkaline phosphatase (ALP) enzyme activity was determined quantitatively using a commercially available ALP kit (Rolf Greiner Biochemica GmbH, Germany) according to the protocol of Tietz et al.. [38]. The ALP activity in the cell-seeded scaffolds was assayed after 1, 2, 3 and 4 weeks. The medium was removed and the scaffolds were washed with phosphate buffered saline (PBS), grinded into powder, dried and frozen at $-20^{\circ} \mathrm{C}$ for $1 \mathrm{~h}$ and lysed with $0.5 \%$ Triton X-100 solution for 30 min at room temperature. An aliquot of the lysed product $(20 \mu \mathrm{l})$ was added to $1 \mathrm{ml}$ of ALP enzyme working reagent and the mixture was incubated at $37^{\circ} \mathrm{C}$. Light absorbance of these samples was measured at $405 \mathrm{~nm}$ at $37{ }^{\circ} \mathrm{C}$ in a UV/visible Spectrophotometer (UV-VisSystem, CN9451, Agilent Technology, Germany). The alkaline phosphatase activity (nanomoles of converted p-nitrophenol/min) was expressed in bar chart as units (U)/ml.

\subsection{Histological analysis}

The scaffolds seeded with cells were extensively rinsed with PBS and fixed with paraformaldehyde at $4{ }^{\circ} \mathrm{C}$ and $70 \%$ ethanol at room temperature. Scaffolds were then dehydrated, embedded in polymethyl methacrylate (PMMA) resin and sectioned $5 \mu \mathrm{m}$. After deplastification, scaffold sections were stained either with $20 \%$ Giemsa or Gömori stain to observe the extracellular matrix formation.

\subsection{Cell morphology by SEM}

The scaffolds seeded with osteoblast-like cells were washed with PBS buffer and fixed with $2 \%$ glutaraldehyde in mixture of PBS and paraformaldehyde solution at room temperature over night. The fixed scaffolds were dehydrated in graded ethanol series of 50, 60, 70,90 and $100 \%$, finally in acetone and critical point dried. The cryo-fractured samples were coated with a thin layer of palladium using a sputter coater (BALTEC, SCD 050) for $30 \mathrm{~s}$ under vacuum. The morphology and proliferation of the cells inside the scaffolds were observed with an environmental scanning electron microscope at $15 \mathrm{kV}$ under low vacuum. 

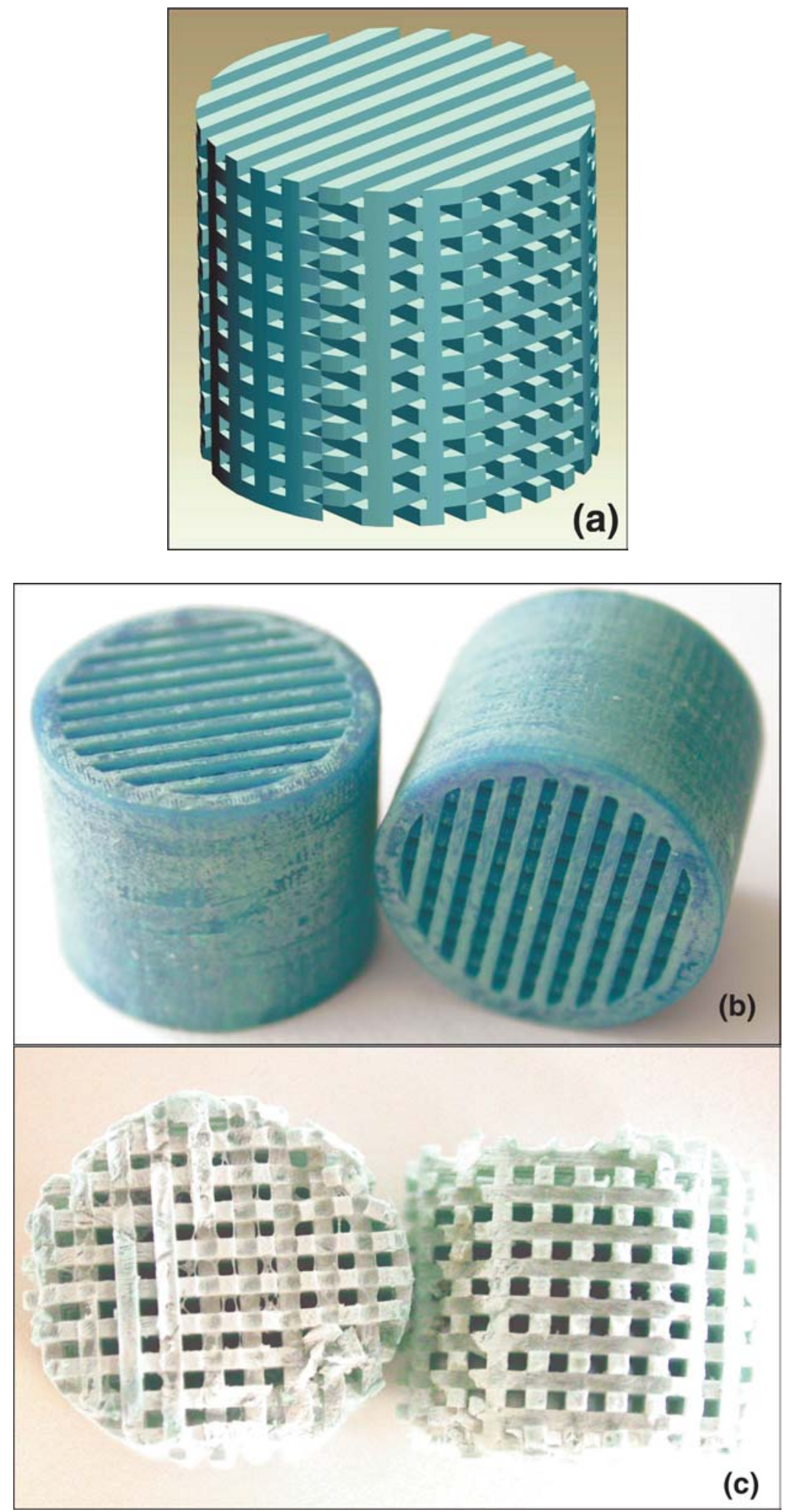

Figure 2 (a) View of CAD design of negative mold with struts running perpendicular to each other. An outer cylindrical layer is build in to hold the slurry during casting, (b) the wax molds produced from Solidscape printer after removal of support wax and (c) top view and side view of the chitosan-hydroxyapatite composite scaffolds showing interconnected pore channel.

\section{Results and discussion}

\subsection{Scaffold characterisation}

\subsubsection{Scaffold architecture}

The view of the CAD design of the mold used for the present study is shown in Fig. 2(a). The virtual design of the scaffold created was a cylinder of $10 \mathrm{~mm}$ height with parallel quadratic struts forming a wood-pile structure. The dimension of one strut and distance between the struts was $500 \mu \mathrm{m}$. The total porosity of such a structure mold is $50 \%$. In our earlier report, HA scaffolds were made of epoxy resin molds produced by DLP, in which the resin was removed while sintering HA scaffolds at high temperatures. Thermal decomposition of the mold is not suitable for polymer ceramic composite scaffolds, since chitosan polymer would be damaged at the necessary temperature of $600{ }^{\circ} \mathrm{C}$. Therefore sacrificial and 


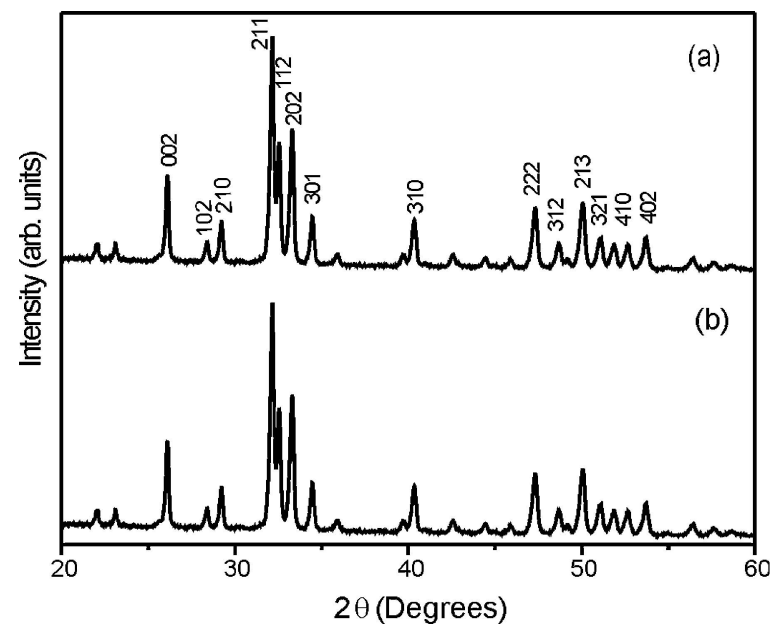

Figure 3 X-ray diffraction patterns of (a) raw hydroxyapatite powder and (b) chitosan-hydroxyapatite composite. The patterns show no difference in HA after processing the scaffold. The peaks corresponding to HA are indexed according to JCPDS 9-432.

dissolvable wax molds produced with inkjet printer system are used for chitosan-HA composite scaffolds. The molds and the scaffolds formed from it are shown in Figs. 2(b) and 2(c), respectively. After being filled with composite and freeze dried (lyophilised), the wax molds were removed out in alcoholic alkaline solution, which also acted as cross-linking for the chitosan polymer. The macro pore channels of the scaffolds, as seen in Fig. 2(c), were predefined as $500 \mu \mathrm{m}$ by the design of the mold. The lyophilisation process induced a microporosity (100-200 $\mu \mathrm{m})$ in the chitosan polymer matrix enhancing the porosity of the scaffolds, while the HA particles remained intact due to cross-linking.
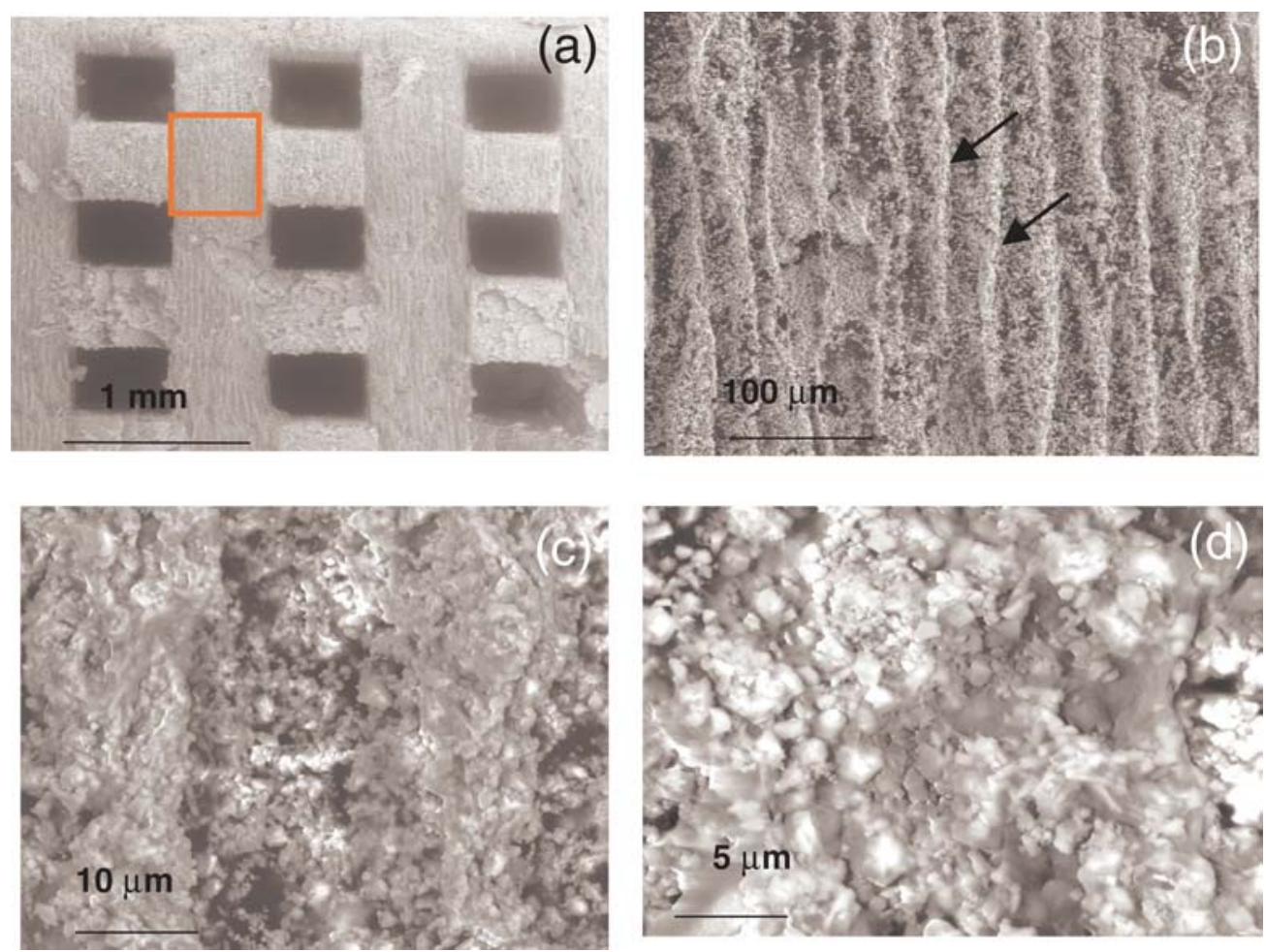

Figure 4 Scanning electron micrographs of composite scaffolds (a) overview of a scaffold, (b) side view of a scaffold parallel to mold print direction, showing surface roughness (marked by arrows), (c) and (d) showing the composite at micron level with a complete blend of chitosan polymer and hydroxyapatite particles. 

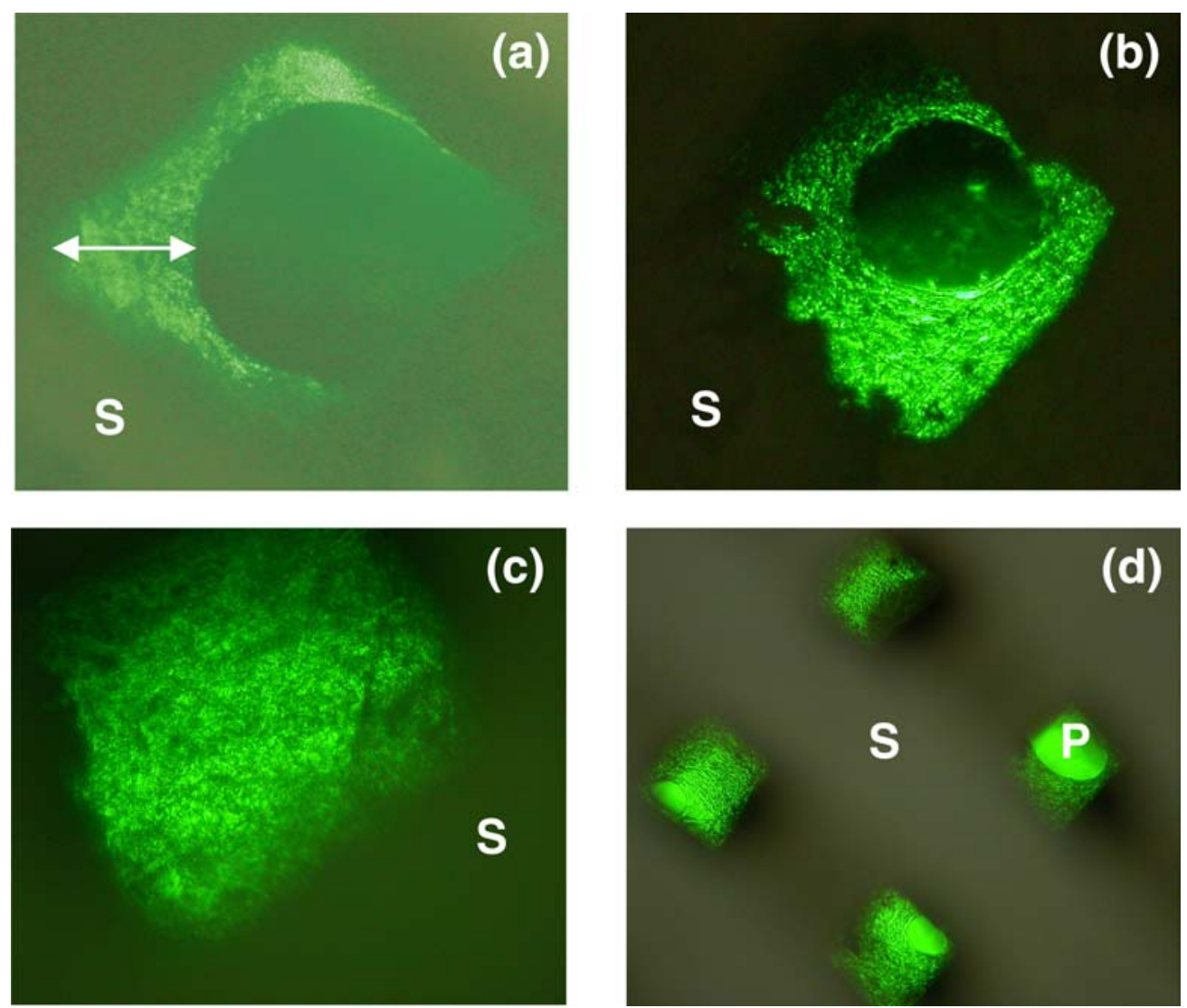

Figure 5 Phase contrast light micrographs of cells cultured on scaffolds viewed after different time periods. (a-c) cells start growing at the corner of the pore channel and start filling the pore after 2 weeks (Magnification: 100×) and (d) overall view of pores (Magnification: $40 \times$ ). Observe that the pores are not homogeneously filling the pores after 3 weeks of culture.

homogeneous distribution as seen from Figs. 4(c) and $4(d)$, respectively. The local Young's modulus of the composite-was assessed by nanoindentation and was found to be in range $15-17 \mathrm{GPa}$, which is close to that of human compact bone (20 GPa) (data not shown).

\subsection{Cell behaviour and growth \\ 3.2.1. Cell growth on scaffolds}

The filling of pores by cells and biogenic matrix was observed by phase contrast microscopy after different time periods of cell culture (Fig. 5). Initially the cells were distributed on exterior surfaces and were forming multi-layers. A confluent layer appeared after 2 weeks. But nevertheless, there was heterogeneity in the proliferation of the cells within the pores, which resulted in a complete closure of several pores, whereas some pores were only partially closed with a cellular network (Fig. 5(d)). Nevertheless, the cell behaviour indicates that the scaffolds are well suited for bone cell attachment, proliferation and differentiation. This observation confirms that both chitosan and HA are good substrate for cell growth.

\subsubsection{Alkaline phosphatase activity}

The differentiation of the osteoblasts can be assessed by monitoring the ALP enzyme activity [44]. ALP activity is an early differentiation marker of the osteoblast phenotype and moreover, ALP is thought to play a critical role in the initiation of matrix mineralisation as the

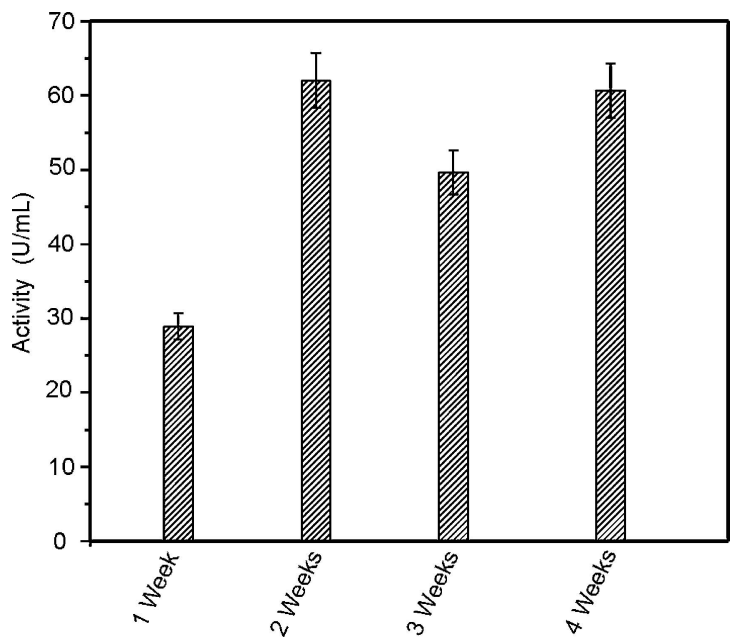

Figure 6 Representation of alkaline phosphatase (ALP) activity of MC3T3-E1 osteoblast cells cultured on composite scaffolds for different time periods.

expression of this enzyme is down regulated after mineralisation starts [45]. The ALP activity of the cells in the scaffolds at different time periods is represented in the Fig. 6. After one week, the ALP activity increased in the cells on the scaffolds. This activity showed a further increase up to two weeks and then maintained at the constant level for the whole culture time (Fig. 6), which showed that the pre-osteoblasts seeded onto the scaffold undergo a differentiation process into direction of a mature phenotype. This result suggests that 

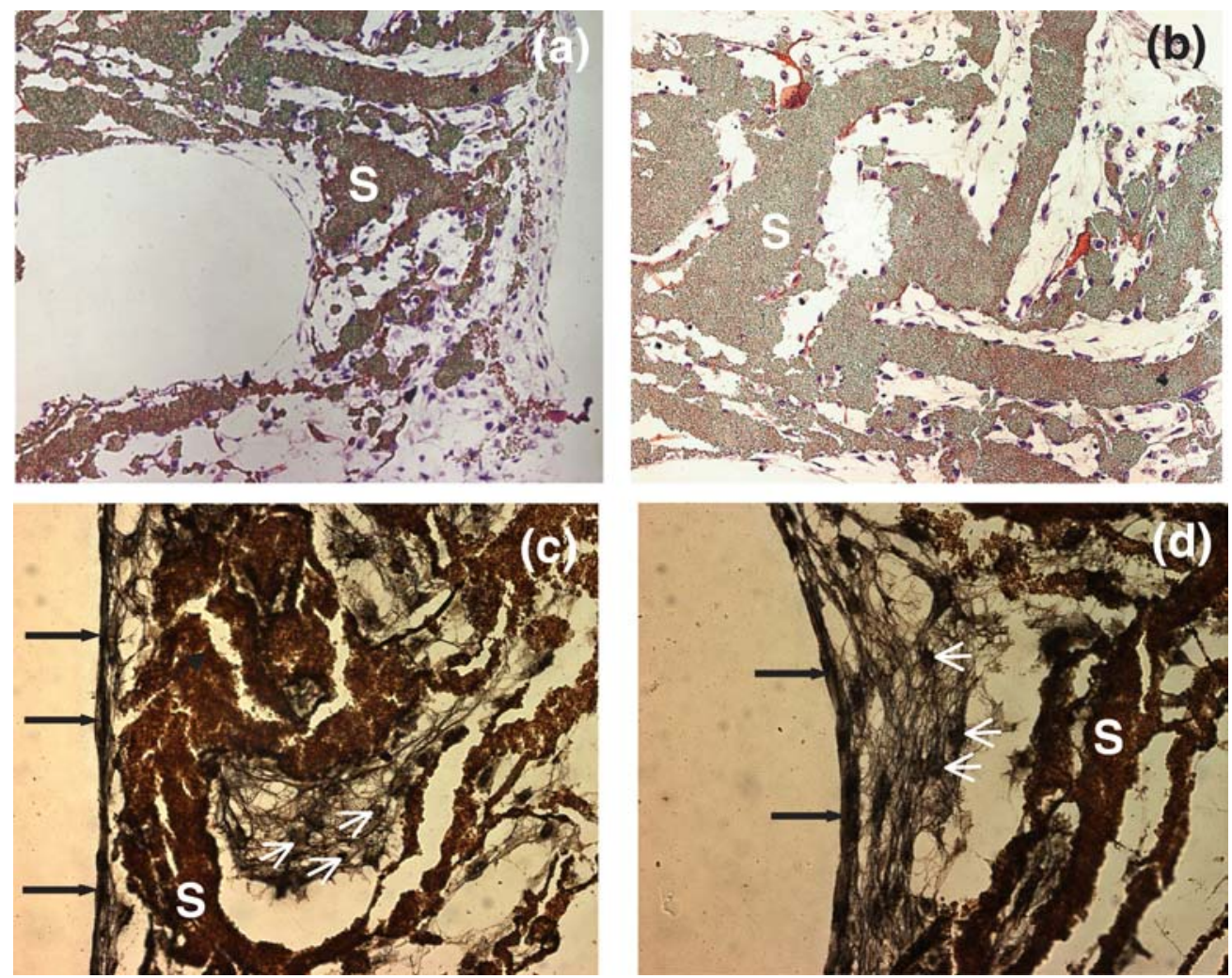

Figure 7 Optical micrographs of stained scaffold sections after 3 weeks of culture time. (a) Giemsa staining reveals cell layer inside the macro pore channel corner (magnification: $100 \times$ ) and (b) showing the cell proliferation inside the micro pore of the scaffold (marked as S) (magnification: $200 \times$ ). (c) and (d) Gömöri staining revealed the formation of extracellular matrix by the cells on the surface of struts and micro pores of the scaffolds (magnification: $400 \times$ ). Observe the cells entrapped within the matrix (marked with arrows) and compare the cuboidal morphology of the cells in the matrix to the normal flattened morphology at the surface (marked by double thick arrows).

the composite scaffold accelerates the osteoblastic differentiation and promotes the formation of extracellular matrix at later stage.

\subsubsection{Histological analysis}

Light micrographs of sections of scaffolds populated with cells stained with Giemsa and Gömori are shown in Fig. 7. Giemsa staining showed that the cells proliferated not only on strut surfaces inside the macro pores (Fig. 7(a)), but also filled the micro pores of the scaffolds (Fig. 7(b)). After 2 weeks culture time, cells were viewed into layers on the surface of the scaffold and occupied preferably corners of the pores as already observed for cells cultured on HA scaffolds [36]. After 3 weeks of culture time, there was further increase of cell layer thickness and collagen.

The histological section stained for Gömori showed a collagen matrix, which surrounded the cells (Figs. 7(c) and $7(\mathrm{~d})$ ) and was deposited by the cells throughout the culture time. The extracellular matrix was observed to increase as a function of culture time and was even observed in micro pore of the scaffold, with cells entrapped in the matrix (Fig. 7(c)). Also at the surface, the multilayered collagen extracellular matrix cells entrapped inside the matrix were viewed (arrows in Figs. $7(\mathrm{c})$ and $7(\mathrm{~d})$ ). The collagen matrix produced by the osteoblastic cells appeared as fine fibrils and formed a network attached to the surface of the scaffold material, which can also be seen in the SEM images of Fig. 8.

\subsubsection{Cell morphology by SEM}

The SEM micrographs show cell attachment and a continuous layer of cells sealing the outer macro pores (Fig. 8). While some of the cells adhered on the macro pore surface and were surrounded by a fibrous extracellular matrix, others spanned the pores in a three dimensional fashion, surrounded by a fibrous extracellular matrix. SEM images showed the adhesion and distribution of cells after 3 weeks on a scaffold. The cells proliferating on the scaffolds exhibited normal flat morphology throughout the culture period comparable to MC3T3-E1 cells growing in conventional culture dishes [46]. The cells started growing at the corners of the macroporous channel filling up the space producing extracellular matrix. They formed multilayers and bridges between the edges of the two struts at the end corners of the scaffolds (Fig. 8(b)). The cells were found also in the microporous region (100-150 $\mu \mathrm{m})$ as shown Fig. 8(d) and even filling up some pores. In comparison to the cells grown on surface, the cells within the micro pores appeared more cuboidal, showing a mature osteoblast phenotype as viewed on the bone surface [47].

Observing the cells in deeper layers, at higher magnification, it is clear that they formed multilayers (as numbered in Fig. 8(e)) and in every layer a network of extracellular matrix (marked as C) is formed. This extra cellular matrix comprises of nano sized collagen fibrils, of the range of $<50 \mathrm{~nm}$ as shown in Fig. 8(f). At some stages, the fibrils exhibited a higher contrast which might indicate a starting of mineralization 

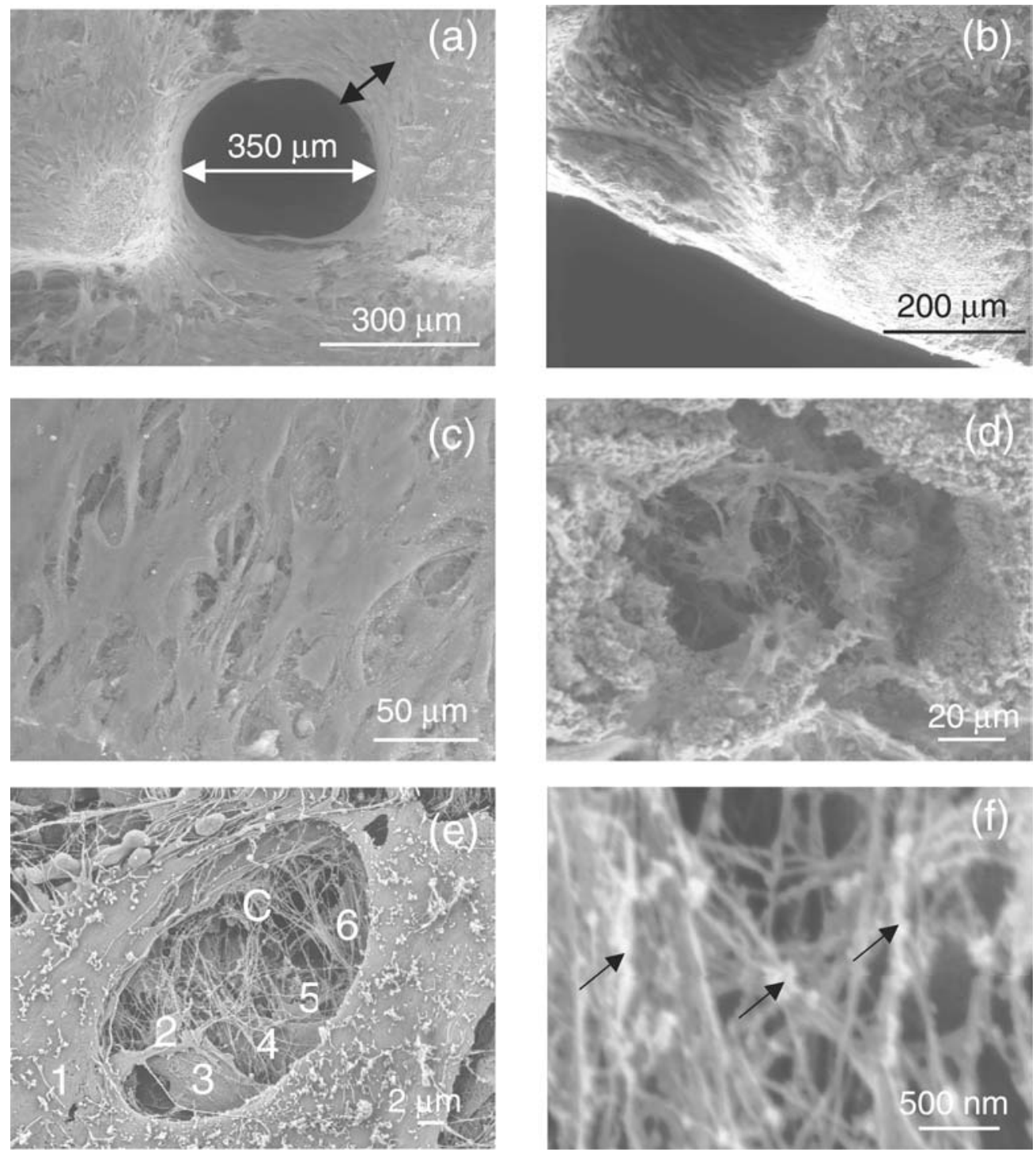

Figure 8 Scanning electron micrographs of cell cultured scaffolds after a period of 3 weeks. (a) pore channel covered by layers of cells forming roundings at the corners of the scaffold struts, (b) the multilayer of cells bridging between the struts at the edge of the scaffold, (c) cells maintaining their flat morphology even after forming multilayers and spreading their filopodia and attaching to each other, (d) the cells move and fill into micro pore region $(100 \mu \mathrm{m})$, (e) showing a typical multilayer of cells (marked with numbers for overlayed cells) and collagen matrix (marked as C) and (f) high resolution image of the collagen fibrils, which are of few nanometers, forming a network. Observe the spots of minerals (marked by arrows) within the matrix highlighted by its contrast in the image.

of the collagen fibrils by clusters of mineral particles (arrows in Fig. 8(f)). This phenomenon seems to be consistent with the observation made by AFM in biomimetic mineralisation of interlaced collagen fibres [48]. Since MC3T3-E1 cells in culture in absence of $\beta$-glycerophosphate, do not mineralise [37], the mineral deposition on the collagen matrix observed in this culture may be due to the presence of mineral (calcium phosphate) particles existing in the scaffold material itself. Further analysis has to be made for confirmation.

\section{Conclusions}

The chitosan-hydroxyapatite composite scaffolds with controlled internal architecture were produced by rapid prototyping. The osteoblast cells colonised the surface of struts of the scaffold and formed a cell-to-cell and cell-to-matrix interconnective network throughout the entire 3D architecture. The unique material properties and ability of chitosan to support viable and function- ing human osteoblasts make the material an attractive candidate for future use in bone and cartilage tissue engineering.

\section{Acknowledgments}

The authors wish to thank Dr. F. Varga, Ludwig Boltzmann Institute of Osteology, Vienna, Austria for gifting the MC3T3-E1 cell line for our work. The technical assistance form Mrs. Gerda Dinst, Ludwig Boltzmann Institute of Osteology, Vienna, Austria is gratefully acknowledged. This study was supported by the AUVA (Austrian Social Insurance for Occupational Risk), by the WGKK (Social Health Insurance Vienna) and the FWF (The Austrian Science Fund) Project \# P16880B13.

\section{References}

1. J. D. CURREY, in "Bones-Structure and Mechanics" (Princeton University Press, Princeton, 2002). 
2. S. Weiner and H. D. WAGNer, Ann. Rev. Mater. Sci. 28 (1998) 271.

3. P. FRATZL, H. S. GUPTA, E. P. PASCHALIS and P. ROSCHGER, J. Mater. Chem. 14 (2004) 2115.

4. R. LANGER and J. P. VACANTI, Science 260 (1993) 920.

5. J. A. HUB BEL, Biotechnology 13 (1995) 565.

6. D. W. HUTMACHER, ibid. 21 (2000) 2529.

7. Idem., J. Biomat. Sci. Poly. Ed. 12 (2001) 107.

8. L. G. CIMA, J. P. VACANTI, C. VACANTI, D. INGER, D. MOONEY and R. LANGER, J. Biomech. Eng. ASME 113 (1991) 143.

9. U. RiPAMONTI, S. MA and A. H. REDDi, Matrix 12 (1992) 202.

10. J. H. KUHNE, R. BARTL, B. FRISCH, C. HAMMER, V. JANSSON and M. ZIMMER, Acta. Orthop. Scand. 65 (1994) 246.

11. EL DEEB and R. HOLMES, J. Oral Maxillofac. Surg. 47 (1989) 1282.

12. A. MAGAN and U. RIPA MONTI, J. Craniofac. Surg. 7 (1996) 71.

13. E. TSURUGA, H. TAKITA, H. ITOH, Y. WAKISAKA and Y. KUBOKI, J. Biochem. 121 (1997) 317.

14. Q. M. JIN, H. TAKITA, T. KOHGO, K. ATSUMI, H. L TOH and Y. KUBOKI, J. Biomed. Mater. Res. 51 (2000) 491.

15. B. S. CHANG, C. K. LEE, K. S. HONG, H. J. YOUN, S. S. RYU, S. S. CHUNG and K. W. PARK, Biomaterials 21 (2000) 1291

16. D. LIU, J. Mater. Sci. Lett. 15 (1996) 419.

17. D. M. LIU, Ceram. Int. 23 (1997) 135.

18. L. E. HUEC, J. SCHAEVERBEKE, T. CLEMENT, D. FABER and J. LE REBELLER, Biomaterials 16 (1995) 113.

19. K. HING, S. BEST and W. B ONFIELD, J.Mater. Sci. Mater. Med. 10 (1999) 135.

20. A. G. MIKOS, A. J. THORSEN, L. A. CZERWONKA, Y. BAO and R. LANGER, Polym. 35 (1994) 1068.

21. M. REUBER, L. S. YU and W. J. KOLFF, Artif. Organs. 11 (1987) 323.

22. R. C. THOMPSON, M. J. YASZEMSKI, J. M. POWERS and A. G. MiKOS, J. Biomat. Sci. Poly. Ed. 7 (1995) 23.

23. A. WOESZ, J. STAMPFL and P. FRATZL, Adv. Eng. Mater. 6 (2004) 134.

24. J. STAMPFL, R. CANO VIVES, S. SEIDLER, R. LISKA, F. SCHWAGER, H. GRUBER, A. WOESZ and P. FRATZL, in Proceedings of the 1st International conference on advanced research in virtual and rapid prototyping, edited by $\mathrm{P}$. J. Bartolo and G. Mitchell, et al. (2003) p. 659.

25. W. Y. YEONG, C. K. CHUA, K. F. LEONG and M. CHANDRASEKARAN, Trends Biotech. 22 (2004) 643.

26. K. J. L. BURG, S. POTER and J. F. KELLAM, Biomaterials 21 (2000) 2347.

27. G. DACULSI, R. Z. LE GEROS, E. NERY, K. LYNCH and B. KREB EL, J. Biomed. Mater. Res. 23(1998) 883.
28. I. MANJUBALA, R.V. SURESH KUMAR and T. P. S ASTRY, J. Biomater. App. 19 (2005) 341.

29. S. MiYAZAKi, K. IShil and T. NADAi, Chem. Pharm. Bull. (Tokyo) 29 (1981) 3067.

30. R. A. MUZARELli, "The Polysaccharides" (New York, Academic Press 1985) p. 417.

31. J. K. SUH and H. W. MATHEW, Biomaterials 21 (2000) 2589.

32. S. V. MADihAlly and H. W. MATHEW, ibid. 20 (1999)1133.

33. R. A. MUZZARELli, M. MATtioli-BELMONTE, C. TIETZ, R. BIAGINI, G. FERIOLI and M. A. BRUNELLI, ibid. 15 (1994) 1075.

34. Z. LI, L. YUBAO, Y. AIPING, P. XUELIN, W. X UEJIANG and Z. XIANG, J. Mater. Sci. Mater.Med. 16 (2005) 213.

35. T. H. ANG and F. S. A. SUlt ANA, Mater. Sci. Eng. C20 (2002) 35 .

36. A. WOESZ, M. RUMPLER, J. STAMPFL, F. VARGA, N. FRATZL-ZELMAN, P. ROSCHGER, K. KLAUSHOFER and P. FRATZL, ibid. C25 (2005) 181.

37. N. FRATZL-ZELMAN, P. FRATZL, H. HORANDNER, B. M. GRABNER, F. VARGA, A. ELlingER, and K. KLAUS HOFER, Bone 23 (1998)511.

38. N. W. TIETZ, D. RINKER and L. M. SHAW, J. Clin. Chem. Clin. Biochem. 21 (1983) 731.

39. P. ROSCHGER, B. M. GRABNER, S. RINNERTHALER, W. TESCH, M. KNEISSEL, A. BERZLANOVICH, K. KLAUSHOFER and P. FRATZL, J. Struct. Biol. 136 (2001)126.

40. K. WHANG, E. HEALY and D. R. ELENZ, Tissue Eng. 5 (1999) 35

41. M. C. WAKE, C. W. PATRICK and A. G. MIKOs, Cell Transplant. 3 (1994) 339.

42. M. SIVAKUMAR, I. MANJUBALA and K. P. RAO, Carb. Polym. 49 (2002) 281.

43. Y. J. YIN, F. ZHAO, X. F. SONG, K. D. YAO, W. W. LU and J. C. LeONG, J. App. Polym. Sci. 77 (2000) 2929.

44. Y. GOTOH, K. HIRAIWA and M. NARAJAMA, Bone and Miner. 8 (1990) 239.

45. H. I. ROACH, Histochem. J. 31 (1999) 53.

46. N. FRATZL-ZELMAN, H. HÖRANDNER, E. LUEGMAYR, F. VARGA, E. Ellinger, M. P. M. ERLEE and K. KLAUSHOFER, Bone 20 (1997) 225.

47. M. P. LYNCH, J. L. STEIN and J. B. LIAN, Dev. Biol. 1966 (1994) 229

48. W. TONG and S. J. EPPEL, J. Biomed. Mater. Res. 61 (2002) 346.

Received 30 June

and accepted 27 July 2005 